Pesq. Vet. Bras. 36(Supl.1):46-50, junho 2016

DOI: $10.1590 / \mathrm{S} 0100-736 \mathrm{X} 2016001300007$

\title{
Animal-assisted therapy in early childhood schools in São Paulo, Brazil ${ }^{1}$
}

\author{
Amanda O. Ferreira ${ }^{2 *}$, Elaine A.F. Rodrigues², Amilton C. Santos ${ }^{2}$, Ricardo R. \\ Guerra $^{3}$, Maria A. Miglino ${ }^{2}$, Durvanei A. Maria ${ }^{4}$ and Carlos E. Ambrósio ${ }^{5}$
}

\begin{abstract}
Ferreira A.O., Rodrigues E.A.F., Santos A.C., Guerra R.R., Miglino M.A., Maria D.A. \& Ambrósio C.E. 2016. Animal-assisted therapy in early childhood schools in São Paulo, Brazil. Pesquisa Veterinária Brasileira 36(Supl.1):46-50. Faculdade de Medicina Veterinária e Zootecnia, Universidade de São Paulo, Rua Prof. Orlando Marques de Paiva 87, São Paulo, SP 05508-270, Brazil. E-mail: olivotti@usp.br

Since ancient times, humans and animals have interacted for different purposes. Animal Assisted Therapy (AAT) is used for the assistance and treatment in humans and educational projects where animals are used as co-therapists or co-educators. The use of animals facilitates the process of teaching and learning, and stimulates physical and therapeutic activities. So that knowledge on AAT could be expanded, current study analyzes the opinion of people directly involved in education on AAT implementation as an educational model in early childhood schools in São Paulo, Brazil. Questionnaires were handed out to 10 pedagogical coordinators, 32 teachers, 23 parents and 26 children aged 3-6 years. Results revealed that AAT is not well-known for most interviewees, including pedagogical coordinators, teachers and parents. However, interviewees believe in the benefits of child-pet interactions and are favorable to the implementation of AATs in schools. Projects should be interdisciplinary and must involve professionals from other areas, such as psychologists and veterinarians. Regarding the educational model, interviewees believe in the innovation capacity of AAT and in the possibilities of interdisciplinarity among teachers in the use of animals. Research also demonstrated that children like and support the use of animals in the school.
\end{abstract}

INDEX TERMS: Child-pet interaction, child therapy, early childhood education, educational projects.

RESUMO.- [Terapia assistida por animais em escolas de educação infantil de São Paulo.] Desde a pré-história já existia a interação dos humanos com os animais com diferentes finalidades. A terapia assistida por animais (TAA) é utilizada para assistências e tratamentos em humanos e projetos pedagógicos, na qual os animais são utilizados como co-terapeutas ou co-educadores. 0 emprego de animais facilita o processo de ensino-aprendizagem e estimula atividades físicas e terapêuticas. Para contribuir com o co-

\footnotetext{
${ }^{1}$ Received on November 19, 2015.

Accepted for publication on February 27, 2016.

${ }^{2}$ Faculdade de Medicina Veterinária e Zootecnia, Universidade de São Paulo (USP), Rua Prof. Orlando Marques de Paiva 87, São Paulo, SP 05508270, Brazil. *Corresponding author: olivotti@usp.br

${ }^{3}$ Centro de Ciências Agrárias (CCA), Universidade Federal da Paraíba (UFPB), Cidade Universitária, Areia, PB 58397-000, Brazil.

${ }^{4}$ Laboratório de Bioquímica e Biofísica, Instituto Butantan, Cidade Universitária, São Paulo, SP 05508-000, Brazil.

${ }^{5}$ Faculdade de Zootecnia e Engenharia de Alimentos, USP, Av. Duque de Caxias Norte 225, Pirassununga, SP 13636-900, Brazil.
}

nhecimento da TAA, o presente trabalho objetivou abordar a opinião de pessoas diretamente relacionadas à escola, a respeito da implantação da TAA, como modelo educacional nas escolas de educação infantil da cidade de São Paulo. Foram aplicados questionários em 10 coordenadores pedagógicos, 32 professores, 23 pais e 26 crianças de 3 a 6 anos de idade. Os resultados encontrados demonstraram que a TAA ainda não é bem conhecida por uma parcela dos entrevistados, incluindo coordenadores pedagógicos, professores e pais de alunos. No entanto, os entrevistados acreditam nos benefícios da interação criança-animal e defendem projetos voltados a implantação da TAA nas escolas, embora estes projetos devam ser interdisciplinares e envolver profissionais de outras áreas, tais como, pedagogos, psicólogos e médicos veterinários. Em relação ao modelo educacional, nossos entrevistados acreditam na capacidade inovadora da TAA, assim como, nas possibilidades de interdisciplinaridade entre os professores no uso dos animais. Também ficou demonstrado que as crianças gostam e apoiam o uso de animais na escola. 
TERMOS DE INDEXAÇÃO: Educação infantil, interação criança-animal, terapia infantil, projetos pedagógicos.

\section{INTRODUCTION}

For thousands of years humans have used animals for many different purposes. The human-animal interaction may have existed approximately 12000 years ago. In fact, the skeletons of animals and dogs were found buried together. Human-animal therapeutic relationship goes far in history and reports are extant on such practice in the writings and myths of Ancient Rome (Levinson 1965).

Animal Assisted Therapy (AAT) was used for the treatment of patients with mental illnesses for the first time and intuitively in 1792. Equotherapy, an AAT modality, was first reported as a medical treatment in the $18^{\text {th }}$ century (Kobayashi et al. 2009) and the first therapy sessions with animals in people with psychic disorders occurred in Germany in 1867. In 1942, the benefits of Facilitated Therapy with Animals (FTA) were efficiently applied to people with physical and mental deficiencies (Santos 2006). The first attempts in the use of animals for therapeutic purposes occurred in Brazil in 1955 (Dotti 2005, Nogueira \& Nobre 2015). Interest was once more concentrated on AAT in the 1990s when AAT centers were established (Dotti 2005) and became scientifically acknowledged in several countries, included the USA, Canada, France (Capote \& Costa 2011), Australia and even in Egypt (Pereira et al. 2007).

Other terms such as Pet Therapy, Pet Psychotherapy (Levinson 1965), Zootherapy and FTA (Capote \& Costa 2011; Nogueira \& Nobre 2015) were previously used instead of the term AAT. So that confusion in the terms would be avoided, the Delta Society (1996), the society that regulates programs with animals in the US, divided therapy with animals into two different programs.

The first program, called Animal-Assisted Activities (AAA), is the development of entertaining, recreation, and motivation and life-quality improvement activities. The second program, called Animal-Assisted Therapy (AAT) deals with interventions, featuring specific criteria and well-defined aims, undertaken by health professionals, aims at developing and improving the social, physical, emotional and cognitive aspects of people involved in the therapeutic process in which the animal is a integrating part of the treatment process (Delta Society 1996).

Besides its medical, psychological and psychiatric benefits, AAT has been inserted within the educational context to facilitate teaching and learning, and the enrichment of knowledge on the human-animal relationships, Ethics, citizenship, humanitarian education, responsible care and the well-being of animals. These topics facilitate the formation of citizens who will be more aware of their concerns for the environment and for all forms of life (Costa-Neto 1999, Alves et al. 2007, Barboza et al. 2007, Peixoto et al. 2009, Silva et al. 2009).

Studies on AAT have demonstrated several assets: in the development of children with or without cognitive defects; in the life-quality of the elderly; in the recovery of illicit drug or alcohol-dependent patients, and in pathologies. Animals are "working animals" and participate positively in the day-to-day life of humans. The life of animals is valorized in their conviviality with humans, while the animals are employed as co-therapists or co-educators (Lev 2003, Silva et al. 2004, Souto 2009).

For some years, the "Pet Smile" project of São Paulo, Brazil, deals with animals that interact with children, young people and adults in hospitals and health institutions. A decrease in prescriptions, a lower occurrence rate in depression and an increase in survival rates after heart attacks have been the result (Leal \& Natalie 2007; Nogueira \& Nobre 2015). Another successful project has been established at the Faculty of Veterinary Medicine and Animal Science of the Universidade de São Paulo in Pirassununga SP Brazil. The "Dr. Escargot" project has proved that animals may be integrated in school and hospitals for ethical and moral improvement to stimulate citizenship and better life-quality in children and the elderly (Kobayashi et al. 2009).

As demonstrated, AAT has been employed by several professionals such as psychologists, physicians, nurses, pedagogues, speech therapists, physiotherapists, veterinarians, occupational therapists and others. It should be employed preferentially by a multidisciplinary team since each professional has a specific knowledge in the area (Machado 2008, Nogueira \& Nobre 2015).

Although studies on AAT are a transcultural phenomenon, historically ancient and geographically disseminated, few studies on the subject have been published. Current analysis aims to demonstrate the opinion of pedagogical coordinators, teachers, parents and children on the knowledge and insertion of AAT as an educational model in government- and private-run schools featuring early childhood education in São Paulo, Brazil.

\section{MATERIALS AND METHODS}

Four different questionnaires on the establishment of AAT in schools were handed to four different groups: Group I consisted of 10 pedagogical coordinators; Group II was formed by 32 teachers; Group consisted of 23 parents of students; Group IV was formed by 26 children aged between 3 and 6 years. In all, 91 people were interviewed (Figure 1). Interviewed people were selected at random from government- and private-run kindergartens in São Paulo, Brazil.

Group I: All interviewed pedagogical coordinators were females, with a degree in Pedagogy, of whom six had a specialization degree and four has a Master's.

Group II: 28 out of the 32 teachers in Children Education were female and four males. They either had a Training College degree or a Pedagogy degree.

Group III: 15 out of the 23 parents were female and 8 male.

Group IV: 17 out of the 26 children were female and 9 were male.

Figure 2 shows the percentage of male and female interviewed people.

Prior to handing out the questionnaires, AAT was explained, underscoring its benefits when applied to groups of students in early education. The theme was exposed to avoid confusion or lack of understanding on the subject matter by the interviewed. The following questionnaires were handed out; options consisted of YES and NOT, with a space for answers.

\section{Group I - Pedagogical coordinators}

A) Have you ever heard of AAT? B) Do you believe in possible benefits for children by employing AAT? C) Do you think child- 


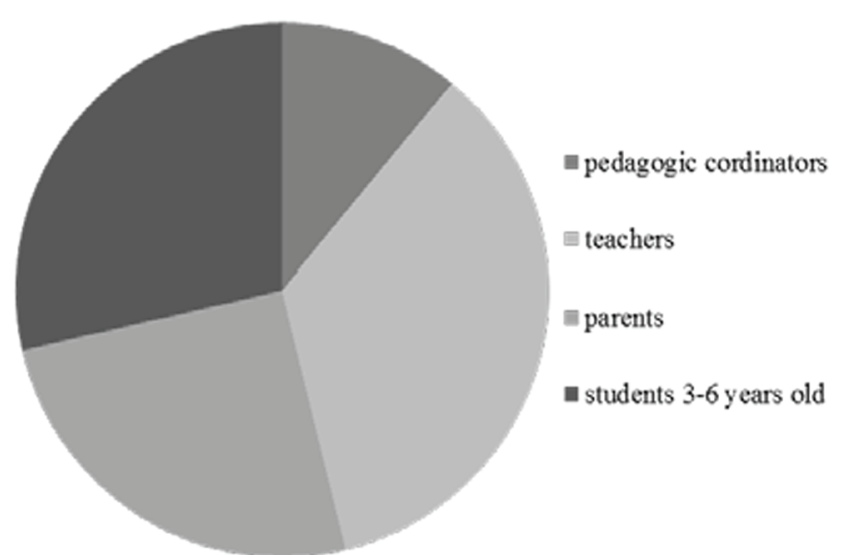

Fig.1. Graph showing the distribution of the four groups of interviewees.

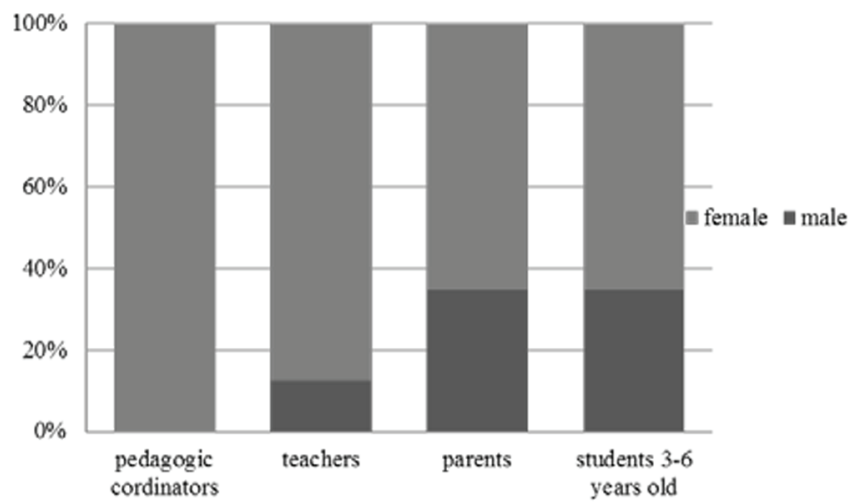

Fig.2. Graph showing percentage of males and females in the different groups.

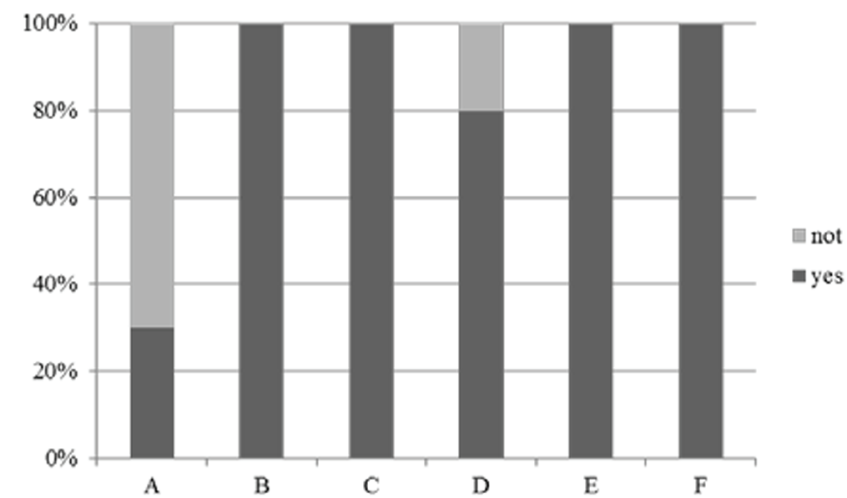

Fig.3. Graph showing percentage of answers in the questionnaire handed to pedagogical coordinators (Group I).

-animal interaction is beneficent? D) What is your opinion if parents accept AAT in the school? E) In your opinion, do you think that it is possible to adopt AAT in current educational model? F) Is AAT possible in your school?

\section{Group II - Teachers}

A) Have you ever heard of AAT? B) Do you believe in possible benefits for children by employing AAT? C) Do you think child-animal interaction is beneficent? D) What do you think on the acceptance of AAT by parents? E) Do you think it is possible to renew the educational model by AAT? F) Do you think interdisciplinarity is possible in the use of animals?

\section{Group III - Parents}

A) Do you like animals? B) Do you have any pets at home? C) Have you ever heard of AAT? D) Do you believe in possible benefits for children by employing AAT? E) What do you think if schools adopt AAT? F) Do you permit your child to participate in the project?

\section{Group IV - 3 to 6-year-old children}

A) Do you like animals? B) Do you have any pets at home? C) Would you like to have pets in school?

\section{RESULTS}

Results were grouped according to the category of the interviewees.

\section{Group I - Pedagogical coordinators}

Questioned whether they had heard anything on AAT (Question A), only 30\% replied positively and that they had a previous knowledge on the theme; the other $70 \%$ never heard about it.

With regard to Question B, the interviewees were unanimous that AAT would be beneficial to children. They were also unanimous on Question C with regard to the benefits for children and animals.

With regard to parents' acceptance (Question D), 80\% replied that acceptance would be good, but $20 \%$ believed than not all parents would let their children participate in the project. Some replied that perhaps a few would oppose the project.

In the case of Question E, all agreed that the educational model would be an efficient educational model since AAT benefits have already been approved in many studies.

When asked whether their schools would adopt the idea in the future (Question F), all the interviewed answered positively. Although the idea was good, a financial planning would be necessary for its execution since, besides physical space, physiotherapists, PT professional and veterinaries would be required. Figure 3 displays the percentage of positive and negative answers so that questions for Group I may be better understood.

\section{Group II - Teachers}

In their answer to Question A, only 5\% reported that they had heard something about AAT; the other $95 \%$ said they hadn't heard anything about the theme.

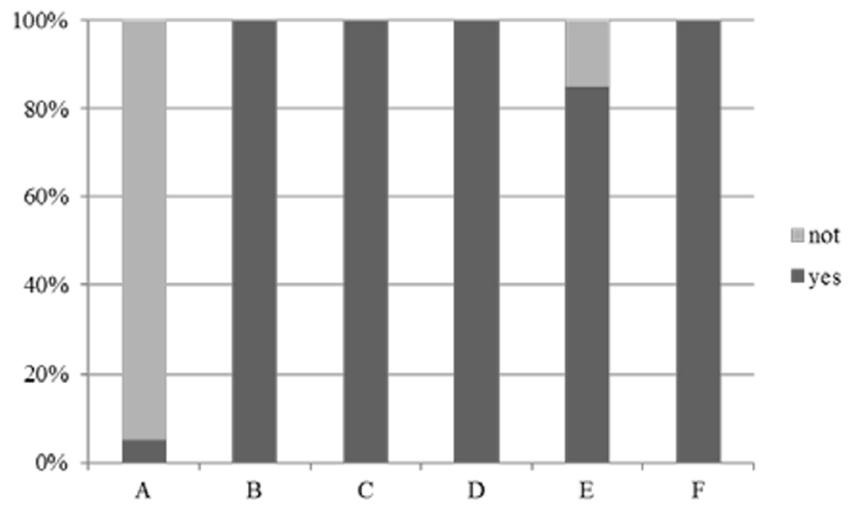

Fig.4. Graph showing percentage of answers in the questionnaire handed to teachers (Group II). 


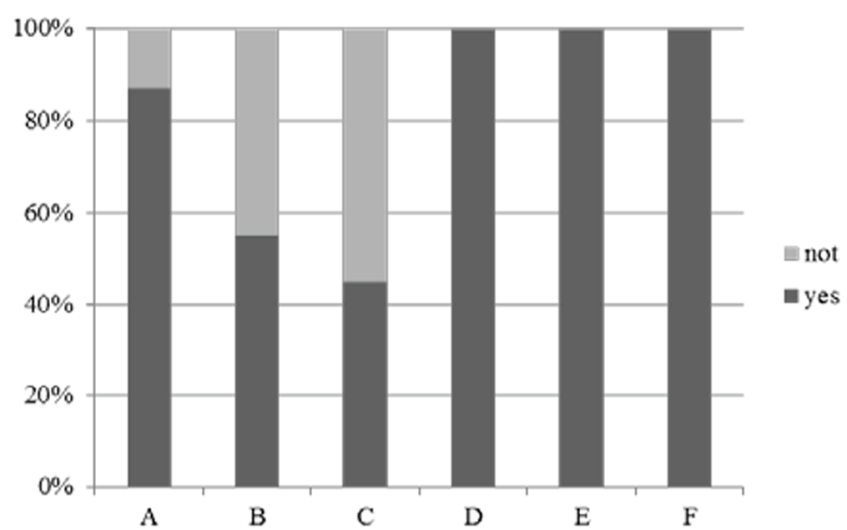

Fig.5. Graph showing percentage of answers in the questionnaire handed to children's parents (Group III).

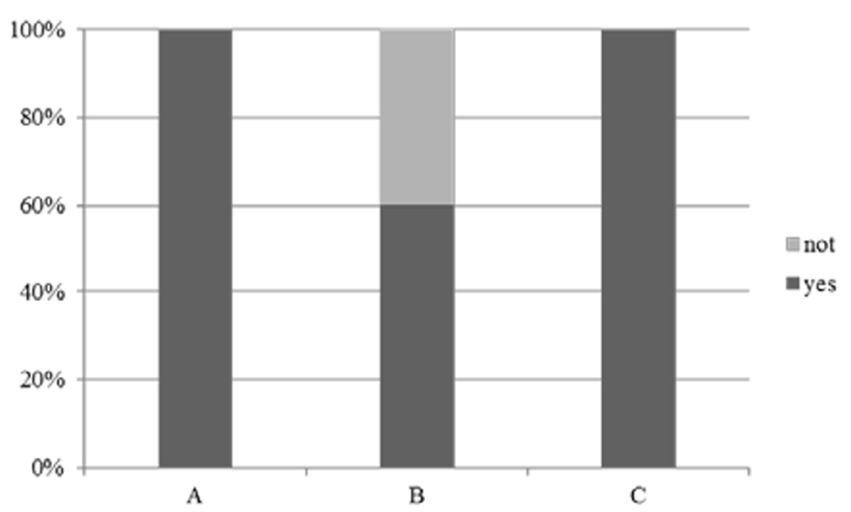

Figure 6. Graph showing percentage of answers in the questionnaire handed to school children (Group IV).

When questioned whether they believed in possible benefits for children (Question B), all interviewed teachers replied positively on the benefits of the project. Similarly, all agreed on the child-animal interactivity (Question C) and replied that it would be easy to undertake and that it would be highly positive for both children and animals.

All the interviewed teachers replied that parents would surely allow their children to participate (Question D) in the project which would be easily accepted by the parents.

When questioned on AAT as a novel educational model (Question E), 85\% of the teachers believe in the project but $15 \%$ said that there would be difficulties to deploy it, such as the place to keep the animals, professional, trainers, feeding and others.

The interviewees unanimously said that multidisciplinarity is a must in teaching and interdisciplinarity between teachers in the use of animals is possible (Question F). Figure 4 shows the percentages of answers by Group II.

\section{Group III - Parents}

When questioned whether they liked animals (Question A), $87 \%$ of the children's parentes answered positively and $13 \%$ replied that they did not. However, $55 \%$ of the interviewed parents have pets at home but $45 \%$ do not (Question B). Further, $45 \%$ of the parents heard about AAT but the others did not (Question C).
All parents answered positively on the benefits for children in their activities with animals (Question D) and they said that the school experience would be interesting (Question E). One of the interviewed stated: "The idea is highly innovative for schools and good results would be obtained. Good results have been obtained with children in other studies".

With regard to Question F on the participation of their children in the project, all agreed that the children would be allowed to participate in the project. Figure 5 gives data on the answers to Questionnaire III.

\section{Group IV - 3 to 6-year-old children}

All the children replied that they liked animals (Question A). Further, $60 \%$ answered they had pets at home; the other 40\% did not (Question B). All the children replied that they would be very pleased to have pets in school (Question C). Figure 6 gives the answers of Group IV.

\section{DISCUSSION}

It must be underscored that, although AAT has been extensively studied during the last few years in deployment projects for hospitals, prisons and schools (Kobayashi et al. 2009), most interviewees, mainly pedagogical coordinators and teachers, do not know anything on the practice and benefits of AAT in children's education. The number of parents unaware of AAT was lower.

Although few people know anything about AAT, several studies have shown that the therapy has been applied to people in different age brackets and in several situations, such as hospitals, clinics, homes for the elderly, schools and physiotherapy and rehabilitation clinics. All types of animals have been employed to contact humans without harming them (Kobayashi et al. 2009). Dogs, cats, birds, fish, horses, rabbits and others have been used in AAT (Cole \& Cole 2003).

All interviewed groups in current research (pedagogical coordinators, teachers and parents) believe that the animal-children interaction is beneficial and good. The dog has been the main animal employed in researches when AAT is applied, since the animal is naturally inclined to people and may be trained easily. Several studies have shown that animals that can be touched produce a more effective therapy and interaction produces positive answer to the touch, with great acceptance by people (Sobo 2006).

The deployment of AAT in schools is accepted positively by pedagogical coordinators, teachers, parents and children. Such a decision is justified since child-animal interaction may be verified in the relationship that the child maintains with animals, which is rather different from that dolls or another inanimate being. Although exchange of words is impossible, the relationship occurs by gestures and movements by which the child established a type of communication with a free release of feelings. Further, during AAT, children have the opportunity of expressing themselves besides learning many things on animals. For instance, children may observe the animals and discuss their behavior with the teacher or researcher and with other 
children. They may discuss how they feel in certain situations. They may learn the characteristics of the animal's race, the care they give, its needs and how to give and receive affection (Dotti 2005).

Research also revealed children's interest in animals, although there are no studies on the use of animals to verify behavioral changes in children without any health disorders. Several studies show the importance of children's social interaction for their development and the benefits of therapy in behavior deviations, deficits or excesses that harm the children's interactivities with their colleagues and adults they live with (Silva 2002). In a study on children in the classroom, the animals provided social and emotional support to children by increasing their self-esteem and increased their ability to express themselves (Friesen 2010).

In fact, AAT has been lately focused upon by psychologists, physicians, nurses, pedagogues, speech therapists, physiotherapists, veterinarians and occupation therapists and may involve a multidisciplinary process for children with cognitive problems. Although its main application is still restricted to therapy, psychology and psychiatry, interest in deploying AAT in schools has been on the increase. Consequently, more and better research work on AAT in education and its dissemination are required as a pedagogical support in schools.

Current research showed that AAT is still rather unknown by a relatively high percentage of the interviewees, including pedagogical coordinators, teachers and parents. However, they believe in the benefits of children-animal interaction and support projects on AAT deployment in schools even though the educational projects must be interdisciplinary, involving psychologists and veterinarians. With regard to the educational method, the interviewed people believe in the AAT's innovatory capacity and in the possibilities of interdisciplinarity among teachers in the use of animals. Needless to say, children love and support the use of animals in school.

Acknowledgements.- Thanks are due to CAPES (Coordenação de Aperfeiçoamento de Pessoal de Nível Superior) for funding the project.

\section{REFERENCES}

Alves R.R.N. \& Rosa I.L. 2007. Zootherapy goes to town: the use of animal-based remedies in urban areas of NE and N Brazil. J. Ethnopharmacol. 113(3):541-555,

Barboza R.R.D., Souto W.M.S. \& Mourão J.S. 2007. The use of zootherapeutics in folk veterinary medicine in the district of Cubati, Paraíba State, Brazil. J. Ethnobiol. Ethnomed 3(1):1-14.

Cole M. \& Cole S. 2003. O desenvolvimento da criança e do adolescente. Artmed, Porto Alegre.

Costa-Neto E.M. 1999. Traditional use and sale of animals as medicines in Feira de Santana City, Bahia, Brazil. Indigenous Knowledge and Dev. Monitor 7(1):6-9.

Delta Society 1996. Standards of Practice in Animal - Assisted Activities and Animal - Assisted Therapy. Delta Society. Renton, WA.

Dotti J. 2005. Terapia e Animais. Paco Editorial, São Paulo.

Friesen L. 2010. Exploring animal-assisted programs with children in school and therapeutic contexts. Early Childhood Ed. J. 37(3):261-267.

Kobayashi C.T., Ushiyama ST., Fakih F.T., Robles R.A.M., Carneiro I.A. \& Carmagnani M.I.S. 2009. Revta Bras. Enfermagem 62(4):632-636.

Lev E. 2003. Traditional healing with animals (zootherapy): medieval to present-day Levantine practice. J. Ethnopharmacol. 85(1):107-118.

Levinson L.M. 1965. Pet Psychotherapy: use of a house hold pets in the treatment of behavior disorders in childhood. Psychol. Reports 17(3): 695-698.

Nogueira M.T.D. \& Nobre M.O. 2015. Terapia assistida por animais e seus benefícios. Pubvet 9(9):414-417.

Peixoto G.C.X., Bezerra-Jr R.Q., Ge D.R.F., Oliveira A.R.M. \& Fonseca Z.A.A.S. 2009. Zooterapia: uma prática essencial. Pubvet 3(18): Art.56.

Pereira M.J.F., Pereira L. \& Ferreira M.M. 2007. Os benefícios da Terapia Assistida por Animais: uma revisão bibliográfica. Saúde Coletiva 4(14):6266.

Silva A.T.B. \& Marturano E.M. 2002. Práticas educativas e problemas de comportamento: uma análise à luz das habilidades sociais. Estudos de Psicologia 7(2):227-235.

Silva M.L.V., Alves A.G.C. \& Almeida A.V. 2004. A zooterapia no Recife (Pernambuco): uma articulação entre as práticas e a história. Biotemas 17(1):95-116.

Silva M.R.S., Martins M.F., Gouvea A.H., Pinheiro J.V., Santos T.R., Lee J.Y., Lins L.B. \& Grechi G.F. 2009. Bem-estar animal em programas de zooterapia ou terapia assistida por animais. Pubvet 3(20): Art.57.

Sobo J.E. 2006. Canine Visitation (pet) Theraphy: pilot data on decreases in child pain perception. J. Holistic Nurs. 24(1):51-57.

Souto W.M.S., Barboza R.R., Mourão J.S. \& Alves R.R. 2009. Zootherapy in Brazil: an urgent necessity of interdisciplinary studies. West Indian Med. J. 58(5):494-495. 